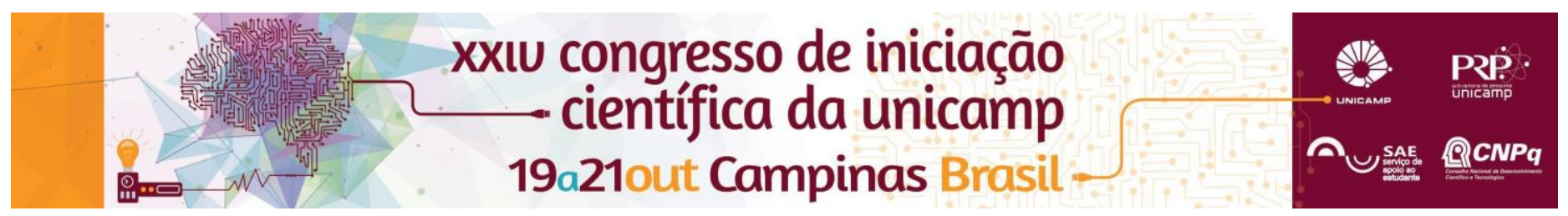

\title{
Análise geoquímica dos depósitos tecnogênicos e solos antrópicos na bacia do Ribeirão das Pedras, Campinas - SP.
}

\author{
Eloise C. Santos*, Cauê C. Pereira*, Francisco S. B. Ladeira, Sara M. Putrino.
}

\section{Resumo}

O homem como agente geológico atua na formação de ambientes antrópicos que no campo da pedologia integram os solos antrópicos e depósitos tecnogênicos. O presente trabalho consiste no estudo dos solos antrópicos e depósitos tecnogênicos coletados na área residencial da bacia do Ribeirão das Pedras em Campinas - SP, os quais serão submetidos a análise química pela técnica de espectrometria de fluorescência de raios-X.

\section{Palavras-chave:}

Solos antrópicos, Depósitos tecnogênicos, Contaminação química do solo.

\section{Introdução}

As transformações no meio ambiente, decorrentes das atividades humanas durante o processo de urbanização, ganham destaque no campo da pedologia como responsáveis pela formação dos depósitos tecnogênicos e solos antrópicos. Por possuir alterações morfológicas e químicas que contribuem para a potencialização dos impactos e desastres naturais, o estudo desses solos se demonstra essencial para uma ocupação urbana bem planejada e com impactos ambientais reduzidos.

O objeto de estudo é a Bacia Hidrográfica do Ribeirão das Pedras, uma sub-bacia do Ribeirão Anhumas, localizada a noroeste do município de Campinas - SP. Foram selecionados nove pontos de estudos caracterizados como terrenos baldios, praças e parques situados dentro da bacia e próximos a domínios residenciais. Assim, o objetivo desse trabalho é identificar as modificações químicas decorrentes da ação humana através das amostras de solo recolhidas, utilizando $o$ procedimento de espectrometria de fluorescência de raios- $X$.

\section{Metodologia}

Nos pontos estudados, houve a abertura de trincheiras, utilizando pás, enxadas e trados, com o propósito de observar o estado pedogenético do local visando, ainda, a identificação de depósitos tecnogênicos (Figuras $1 \mathrm{e}$ 2). A abertura das trincheiras, bem como a classificação dos horizontes e coleta de amostras de solo foram feitas conforme o Manual de Descrição e Coleta de Solo no Campo (Santos, 2005).
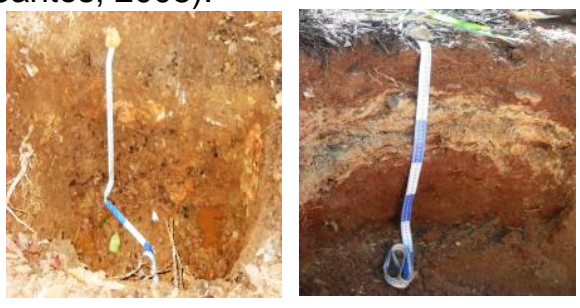

Figura 1. Perfis do ponto 1 (esquerda) e ponto 2 (direita).
As amostras coletadas serão submetidas a análises químicas no Laboratório de Geoquímica do Instituto de Geociências da Unicamp, pelo método de espectrometria de fluorescência de raios- $X$. Esse processo permite a determinação da concentração dos elementos químicos de forma simples e rápida.

\section{Resultados Esperados}

$\mathrm{Na}$ coleta de amostras de solo nos pontos estudados foi possível encontrar materiais de origem antropogênica durante as escavações de trincheiras para a descrição dos perfis pedogenéticos (Figura 2). Esses artefatos, provenientes principalmente de descarte de construção civil, consistiam em telhas, tijolos, blocos de concreto, tubos de plástico, porcelanato e pedaços de madeira.

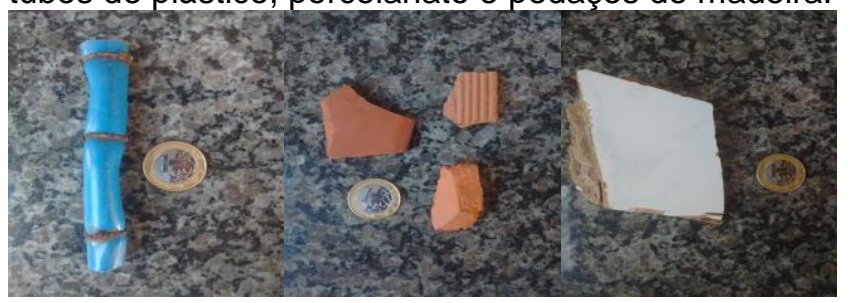

Figura 2. (à esquerda) tubo de plástico encontrado na primeira trincheira do ponto 2; (ao centro) pedaços de telha e tijolo encontrados nas trincheiras do ponto 2; (à direita) porcelanato branco encontrado na terceira trincheira do ponto 2 .

Por meio das amostras de solo coletadas em campo pretende-se identificar as substâncias químicas, potencialmente tóxicas, incorporadas ao solo através da ação antrópica.

\section{Agradecimentos}

Aos nossos pais, por sempre nos proporcionar suporte.

Santos, R. D. et al; Manual de descrição e coleta de solo no campo. $5^{\text {a }}$ ed. Revista e ampliada Viçosa, Sociedade Brasileira de Ciências de Solo, 2005. 